\title{
Strategies to eliminate hepatitis C in Croatia, a modelling study
}

\author{
Strategije za eliminaciju hepatitisa C u Hrvatskoj, studija modeliranja \\ Adriana Vince', Ellen Dugan², Tatjana Nemeth-Blažić3, Tajana Filipec ${ }^{4}$, Irena Hrstic ${ }^{5}$, Boris Lukšić ${ }^{6}$, \\ Diana Nonkovic ${ }^{7}$, Tatjana Reic ${ }^{8}$, Samantha Coleman ${ }^{2}$, Homie Razavi², Sarah Blach ${ }^{2 \bowtie}$ (D) \\ ${ }^{1}$ Medical School University of Zagreb, University Hospital of Infectious Diseases Zagreb, Zagreb, Croatia \\ ${ }^{2}$ Center for Disease Analysis (CDA) Foundation, Lafayette, Colorado, United States \\ ${ }^{3}$ Croatian Institute of Public Health \\ ${ }^{4}$ Merkur Hospital Zagreb, Croatia \\ ${ }^{5}$ General Hospital Pula, Pula, Croatia \\ ${ }^{6}$ Clinical Department of Infectious Diseases, Split University Hospital and Split University Medical School, Split, Croatia \\ ${ }^{7}$ Department of Epidemiology, Institute of Public Health, County of Dalmatia, Split, Croatia \\ ${ }^{8}$ European Liver Patients Association, Sint-Truiden, Belgium
}

\section{Descriptors}

HEPATITIS C - diagnosis, epidemiology, prevention and control; NATIONAL HEALTH PROGRAMS - trends; CROATIA - epidemiology;

WORLD HEALTH ORGANIZATION;

MODELS, THEORETICAL

Deskriptori

HEPATITIS C - dijagnoza, epidemiologija, prevencija;

NACIONALNI ZDRAVSTVENI PROGRAMI - trend;

HRVATSKA - epidemiologija;

SVJETSKA ZDRAVSTVENA ORGANIZACIJA:

TEORETSKI MODELI
SUMMARY. Background: Since a 2016 analysis on the epidemiology and disease burden of HCV in Croatia, the HCV treatment paradigm has shifted substantially. Fibrosis restrictions were removed, and the number of patients treated tripled. With these encouraging changes to policy and practice, an updated analysis was completed to guide resource allocation and a national strategic plan for HCV elimination in Croatia. Methods: A comprehensive literature review and discussions with in-country experts were used to identify epidemiological factors defining HCV disease burden in Croatia. An HCV disease burden model, seeded with this data, was used to assess the impact of increasing screening rates and delineate the steps needed to reach the World Health Organization's (WHO) Global Health and Sector Strategy hepatitis C elimination targets. Results: Achieving WHO elimination targets would reduce the number of viremic cases of HCV from 21,000 in 2015 to 4,000 by 2030 while averting 500 liver-related deaths, and 680 cases of hepatocellular carcinoma and decompensated cirrhosis from 2015 to 2030, relative to the projections under the current standard of care. Screening practices will need to ramp up to testing about 250,000 Croatians annually so that about 1,500 patients can be diagnosed and treated each year. Conclusions: Elimination requires a coordinated effort between country and industry leaders including government authorities, policymakers and healthcare and insurance providers. Improved screening mechanisms will be needed for the scale-up required to achieve goals.

SAŽETAK. Uvod: Nakon posljednje analize epidemioloških i kliničkih podataka o HCV infekciji iz 2016. godine došlo je do velikih promjena u paradigmi liječenja. Uklonjene su restrikcije vezane uz uznapredovali stadij fibroze jetre, a broj liječenih se utrostručio. S obzirom na ohrabrujuće činjenice u mogućnostima liječenja napravljena je nova analiza, koja će peciznije usmjeriti prioritete i alokaciju resursa za provedbu nacionalnog akciiskog plana za eliminaciju hepatitisa C. Metode: Opsežan pregled literature i razgovori s hrvatskim stručnjacima korišteni su za identificiranje epidemioloških čimbenika koji definiraju opterećenje bolešću uzrokovanom virusom hepatitisa C u Hrvatskoj. Dobiveni podatci korišteni su u postojećem matematičkom modelu za procjenu opterećenja bolešću uzrokovanom HCV-om (engl. HCV disease burden model), kako bi se procijenio učinak povećanih stopa probira (engl. screening) i zacrtao putokaz potrebnih koraka za dostizanje globalnih ciljeva Strategije Svjetske zdravstvene organizacije (SZO) za eliminaciju hepatitisa C. Rezultati: Postizanje ciljeva SZO-a značilo bi redukciju HCV viremičnih slučajeva na 4.000 u 2030. uz sprječavanje 500 smrtnih ishoda uzrokovanih bolestima jetre i 680 slučajeva hepatocelularnog karcinoma i dekompenzirane ciroze u razdoblju od 2015. do 2030., za koje se procjenjuje da bi nastali uz sadašnju razinu probira i kliničku praksu. Prema upotrijebljenom matematičkom modelu to bi zahtijevalo povećanje broja testiranja na 250.000 osoba godišnje, kako bi se godišnje dijagnosticiralo i liječilo 1.500 pacijenata. Zaključak: Eliminacija virusnih hepatitisa kompleksan je proces koji zahtijeva koordinirane aktivnosti i suradnju između medicinskih stručnjaka, državne politike, donositelja odluka i pružatelja zdravstvenog osiguranja. Povećanje opsega probirnog testiranja bit će ključno za postizanje ciljeva SZO-a u Hrvatskoj.

\section{Background}

Viral hepatitis is a leading cause of death and affects one in 50 people worldwide. ${ }^{1}$ Around $1 \%$ of the world's population has viremic hepatitis $\mathrm{C}$ virus $(\mathrm{HCV})^{2}$ and are at-risk of developing advanced-stage disease

\section{Corresponding Author:}

Sarah Blach MHS, https://orcid.org/0000-0002-9252-7576

CDA Foundation, 1120 W. South Boulder Rd. Suite 102, Lafayette, Colorado, USA e-mail: sblach@cdafound.org

Primljeno 10. siječnja 2020., prihvaćeno 18. svibnja 2020. 
TAble 1. Epidemiologic inputs used to model the BURden of HCV, Croatia

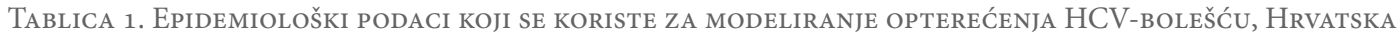

\begin{tabular}{|c|c|c|c|}
\hline $\begin{array}{l}\text { Parameter } \\
\text { / Parametar }\end{array}$ & $\begin{array}{l}\text { Value (Range) } \\
\text { / Vrijednost (Raspon) }\end{array}$ & $\begin{array}{l}\text { Estimate Year } \\
\text { (EoY) } \\
\text { / Godina procjene } \\
\text { (kraj godine) }\end{array}$ & Source / Izvor \\
\hline $\begin{array}{l}\text { HCV-RNA positive infections } \\
\text { / HCV-RNA pozitivne infekcije }\end{array}$ & $21,800(20,500-34,200)$ & 2010 & $\begin{array}{l}\text { Vilibić-Čavlek } \\
2014,{ }^{11} \mathrm{PC}^{12}\end{array}$ \\
\hline HCV genotype / HCV genotip & $\begin{array}{l}56.6 \% \mathrm{G} 1[18.8 \% \mathrm{G} 1 \mathrm{a} \text { and } 23.2 \% \\
\mathrm{G} 1 \mathrm{~b}], 37.3 \% \mathrm{G} 3,4.2 \% \mathrm{G} 4,1.6 \% \\
\mathrm{G} 2\end{array}$ & 2018 & Vince $2018^{13}$ \\
\hline Total diagnosed / Ukupno dijagnosticirani (HCV-RNA) & 4,000 & 2014 & EC \\
\hline $\begin{array}{l}\text { Annual newly diagnosed } \\
\text { / Godišnje novo dijagnosticirani (HCV-RNA) }\end{array}$ & 170 & 2018 & EC \\
\hline Annual treated / Godišnje liječeni & 470 & 2018 & $\mathrm{EC}$ \\
\hline $\begin{array}{l}\text { Percent of the infected population infected through transfusion } \\
\text { / Postotak populacije zaražene transfuzijom }\end{array}$ & $23 \%$ & 2018 & EC \\
\hline $\begin{array}{l}\text { Percent of the infected population that are people who inject } \\
\text { drugs actively } \\
\text { / Postotak zaražene populacije koji aktivno injiciraju drogu }\end{array}$ & $14 \%$ & 2010 & $\begin{array}{l}\text { PC, }{ }^{12} \text { Kolaric } \\
2010^{15}\end{array}$ \\
\hline
\end{tabular}

EC - expert consensus / stručni konsenzus; EoY - end of year / kraj godine; HCV - hepatitis C / virus hepatitisa C; PC - personal communication / osobna komunikacija.

including liver cirrhosis, hepatocellular carcinoma (HCC), and liver-related death. Despite the success of direct-acting antivirals (DAAs), HCC is an ongoing risk for some patients successfully treated for HCV, particularly those with advanced cirrhosis. ${ }^{3}$ This research highlights the importance of disease prevention and timely linkage to care following diagnosis.

In 2016, we presented both the historical epidemiology of HCV in Croatia ${ }^{4}$ and an analysis of future HCV disease burden. ${ }^{5}$ In the past three years, substantial changes have been made to the HCV treatment paradigm in Croatia. Starting in 2018, all fibrosis restrictions were removed, although prioritization remains in place to guarantee prompt treatment for more advanced-stage patients. Treatment eligibility, previously restricted to adults aged 20-70 years, was expanded in 2018 to cover patients aged $18-84$ years. The annual number of patients treated also tripled from the 2015 to 2018. With these encouraging changes to policy, an updated analysis was conducted to guide development of a national strategic plan and to strengthen surveillance efforts.

This analysis models the interventions needed to achieve WHO targets in addition to various screening strategies. Since HCV is more prevalent in older aged Croatians and in people who inject drugs, we modeled screening efforts for various population cohorts. Data inputs from previous analyses were also re-evaluated and updated with input from Croatian experts in the field of hepatitis. This analysis serves to guide decision-making and resource allocation to eliminate $\mathrm{HCV}$ in Croatia.

\section{Methods}

In January 2019, epidemiologists with the Centers for Disease Analysis Foundation (CDAF) completed a comprehensive literature search for epidemiologic factors associated with HCV infection in Croatia. Over the following three months, CDAF employed a Delphi process to facilitate discussions with in-country experts and reach consensus on epidemiologic inputs by reviewing available estimates and sharing unpublished research and insights. The data collected from this exercise were then input into a disease burden model that has been described in detail previously. ${ }^{2}$ Analyses using this model have been published extensively in other countries and regions, including the original publication for Croatia in 2016..$^{5-8}$

\section{HCV disease burden model}

The Microsoft ${ }^{\oplus}$ Excel-based Markov model uses annual disease progression rates to simulate the natural history of HCV through disease stages from acute hepatitis (considering spontaneous clearance) to chronic fibrosis and end-stage outcomes (including hepatocellular carcinoma, decompensated cirrhosis, liver transplantation and liver-related death). ${ }^{9}$ The model is seeded with population and background mortality data specific to Croatia ${ }^{10}$ as well as countrylevel HCV epidemiological data (Table 1). New infections entering the model were back-calculated between 1950 and 2018 using known prevalence. Annual case counts were calculated by applying a progression rate to each disease stage and adjusted for all-cause mortality, ageing, and cure. All-cause mor- 


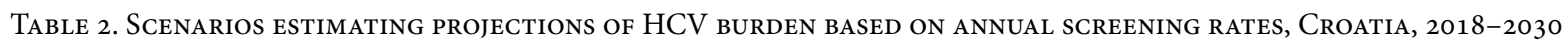

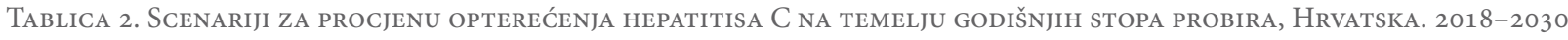

\begin{tabular}{|c|c|c|c|c|c|c|c|c|}
\hline Scenario / Scenario & Model parameter / Parametar & 2018 & 2019 & 2020 & 2022 & 2024 & 2026 & 2028 \\
\hline \multirow{4}{*}{$\begin{array}{l}\text { Base } \\
\text { / Polazište }\end{array}$} & Screened / Broj testiranih & 33,400 & 40,800 & 40,600 & 38,600 & 35,700 & 33,500 & 32,000 \\
\hline & $\begin{array}{l}\text { Newly diagnosed } \\
\text { / Novo dijagnosticirani }\end{array}$ & 170 & 210 & 210 & 210 & 210 & 210 & 210 \\
\hline & Treated / Liječeni & 470 & 470 & 470 & 400 & 320 & 250 & 250 \\
\hline & New infections / Nove infekcije & 140 & 140 & 130 & 120 & 120 & 110 & 110 \\
\hline \multirow{4}{*}{$\begin{array}{l}\text { Screen } \\
\text { / Testirano } 75,000\end{array}$} & Screened / Broj testiranih & 33,400 & 40,800 & \multicolumn{5}{|c|}{75,000 per year } \\
\hline & $\begin{array}{l}\text { Newly diagnosed } \\
\text { / Novo dijagnosticirani }\end{array}$ & 170 & 210 & 740 & 710 & 680 & 610 & 610 \\
\hline & Treated / Liječeni & 470 & 470 & 670 & 640 & 610 & 550 & 550 \\
\hline & New infections / Nove infekcije & 140 & 140 & 130 & 120 & 110 & 100 & 100 \\
\hline \multirow{4}{*}{$\begin{array}{l}\text { Screen } \\
\text { / Testirano } 100,000\end{array}$} & Screened / Broj testiranih & 33,400 & 40,800 & \multicolumn{5}{|c|}{100,000 per year } \\
\hline & $\begin{array}{l}\text { Newly diagnosed } \\
\text { / Novo dijagnosticirani }\end{array}$ & 170 & 210 & 980 & 930 & 870 & 720 & 720 \\
\hline & Treated / Liječeni & 470 & 470 & 880 & 830 & 780 & 650 & 650 \\
\hline & New infections / Nove infekcije & 140 & 140 & 120 & 120 & 100 & & 90 \\
\hline \multirow{4}{*}{$\begin{array}{l}\text { Graduated Screening } \\
\text { + Link to Care } \\
\text { / Probir+Uključivanje } \\
\text { u skrb }\end{array}$} & Screened / Broj testiranih & 33,400 & 40,800 & 75,000 & \multicolumn{4}{|c|}{100,000 per year } \\
\hline & $\begin{array}{l}\text { Newly diagnosed } \\
\text { / Novo dijagnosticirani }\end{array}$ & 170 & 210 & 740 & 940 & 880 & 750 & 750 \\
\hline & Treated / Liječeni & 470 & 470 & $670+270$ & $850+200$ & $820+90$ & $690+30$ & $680+50$ \\
\hline & New infections / Nove infekcije & 140 & 140 & 130 & 120 & 100 & 90 & 90 \\
\hline \multirow{4}{*}{$\begin{array}{l}\text { WHO Elimination } \\
\text { Targets } \\
\text { / SZO eliminacijski } \\
\text { ciljevi }\end{array}$} & Screened / Broj testiranih & 33,400 & 40,800 & 75,600 & 151,000 & 224,000 & \multicolumn{2}{|c|}{ *avg 273,000 per year } \\
\hline & $\begin{array}{l}\text { Newly diagnosed } \\
\text { / Novo dijagnosticirani }\end{array}$ & 170 & 210 & 740 & 1,400 & 1,800 & 1,000 & 1,000 \\
\hline & Treated / Liječeni & 470 & 470 & $670+300$ & $1,300+300$ & $1,600+300$ & 900 & 900 \\
\hline & New infections / Nove infekcije & 140 & 140 & 130 & 120 & 100 & 40 & 40 \\
\hline
\end{tabular}

* Average number of patients screened annually from 2026-2028 in the WHO Elimination Targets scenario (278,000 to 324,000 range). / Prosječni broj testiranih godišnje od 2026. do 2030. prema eliminacijskim ciljevima SZO-a (raspon 278,000-324,000)

tality rates (extracted from the United Nations mortality database) were adjusted to increase incrementally in relation to transfusion and injection drug use trends.

\section{Epidemiologic inputs to estimate}

$\mathrm{HCV}$ disease burden

A full list of epidemiological inputs is included in Table 1. Since many of the historical inputs have remained consistent with the original analysis, ${ }^{4}$ only inputs that have changed are described in detail here.

HCV-RNA Positive Infections - There were an estimated 21,980 Croatians chronically infected with viremic HCV (0.51\% prevalence) in 2010 . This was calculated by adjusting the reported adult anti-HCV prevalence estimate $(0.90 \%$ anti-HCV among adults aged $20-85$ in 2010$)^{11}$ to account for all ages $(0.73 \%$ anti$\mathrm{HCV}$ among all ages in 2010) and applying a 70\% vire- mic rate. ${ }^{12} \mathrm{HCV}$ Genotype - Data from the three largest Croatian national laboratories collected over nine years on 3,655 patients reported the majority of infections were genotype $3,1 \mathrm{~b}$ and $1 \mathrm{a}$, respectively. ${ }^{13}$ Total and Annual Diagnosed - The number of people diagnosed via antibody or RNA testing and reported to the Croatian Institute of Public Health was available annually for 1994-2018. ${ }^{14}$ Experts estimated that 4,000 total patients were diagnosed with chronic HCV as of 2014. This is based on an estimated average of 300 diagnoses annually from 1993-2010 and an estimated average of 200 diagnoses annually from 2011-2014, with adjustments for $70 \%$ viremia $^{12}$, mortality and cured patients. ${ }^{10}$ Annual Treated - In 2018, about 470 patients were treated, and treatment eligibility was expanded from $\geq \mathrm{F} 3$ to remove all restrictions (expert input). Risk Factors - Two risk factors associated with a higher HCV-related mortality were included in the model. 


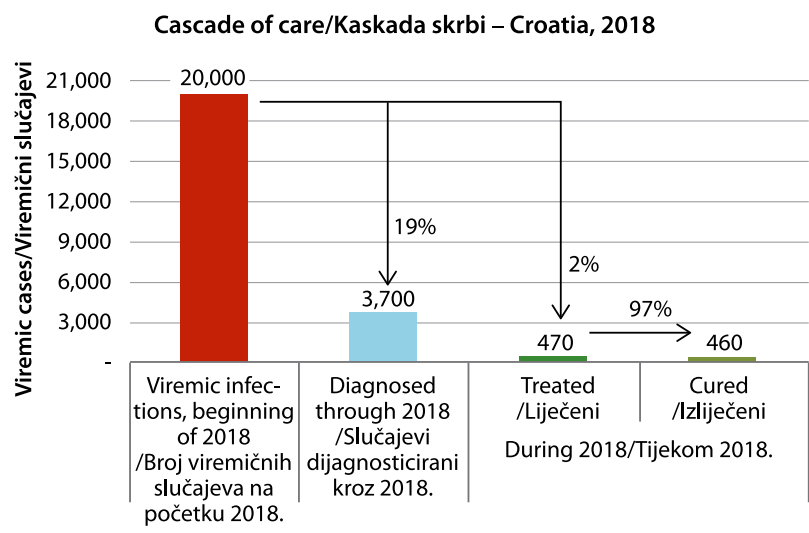

Figure 1. The HCV CASCAde OF CARE, INCluding THE total NUMBER OF VIREMIC INFECTIONS, THE NUMBER OF DIAGNOSED PATIENTS, AND THE NUMBER OF PATIENTS TREATED AND CURED, Croatia, 2018

SLIKA 1. HCV-KASKADA SKRBI, UKLJUČUJUĆI UKUPNI BROJ VIREMIČNIH SLUČAJEVA, BROJ DIJAGNOSTICIRANIH PACIJENATA I BROJ LIJEČENIH I IZLIJEČENIH PACIJENATA U HRVATSKOJ 2018

Experts estimated that $23 \%$ of 2018 total infections resulted from a blood transfusion and that $14 \%$ of the infected population were among people who inject drugs actively (injecting within the last year [PWID]). The PWID population was calculated by first estimating the number of drug users in Croatia $(n=15,444)^{15}$, of which experts estimated 74\% were PWID. After applying a $35 \%$ anti-HCV prevalence among PWID $^{16}$ and adjusting for $70 \%$ viremia $^{12}, 2,800 \mathrm{HCV}$-RNA positive PWID are estimated for 2018; $14 \%$ of total infections $(n=2,800 / 20,000)$. The number of liver transplants were available from $1999-2017^{17}$, of which $15 \%$ were estimated to be HCV-related (expert input).

\section{Scenarios}

After seeding the model with Croatia-specific epidemiological factors, the Base scenario and four intervention scenarios were modeled for 2015-2030 (Table 2). Data from 2015 is the baseline measure in the World Health Organization's Global Health Sector Strategy hepatitis elimination targets (WHO elimination targets) and was therefore utilized as the starting point for all scenarios. ${ }^{2}$ As of 2018, all treatment restrictions based on fibrosis stage and patient age were dropped, such that for all five scenarios, patients aged 18-84 and fibrosis stages F0-F4 were eligible for treatment with high sustained virologic response (SVR) therapies. ${ }^{18}$

Screening trends were assessed for 2018-2030, under the following assumptions. Base: in 2018 and 2019, HCV screening occurred primarily through blood donation centers, voluntary centers, laboratories and screening vans. As a result, the average prevalence in the population screened is estimated to be the same as the general population prevalence in Croatia. Inter- vention Scenarios: Future screening campaigns are expected to target mixed-risk populations through primary care centers (estimated to be an average of twice the general population prevalence, in 2020) (Appendix, Table 2). To account for loss to follow-up within screening campaigns, only $90 \%$ of newly diagnosed patients were estimated to be initiated on treatment annually. Finally, it was assumed that procedures would be optimized to screen each individual only once.

Base - Objective: Model the current standard of care for HCV in Croatia. Assumptions: In 2018 and 2019, 30,000-40,000 patients were screened annually, of which 170 were diagnosed with viremic HCV and reported to the Croatian Institute of Public Health. The number of patients treated each year with DAAs, estimated at 470 patients in 2018, was expected to drop rapidly starting in 2022 to reflect a decreasing pool of previously diagnosed patients (expert input).

Screen $75 \mathrm{~K}$ - Objective: Estimate the impact of an awareness campaign to increase screening rates. $A s$ sumption: Screen 75,000 Croatians annually, starting in 2020.

Screen 100K - Objective: Estimate the impact of an awareness campaign to ambitiously increase screening rates. Assumption: Screen 100,000 Croatians annually, starting in 2020.

Graduated Screening + Link to Care - Objective: Estimate the impact of an awareness campaign to ramp up screening over time while improving linkage to treatment for previously diagnosed patients. Assumptions: Increase screening to 100,000 people annually, by 2022 . Treat patients who were diagnosed in previous years but were lost to follow-up.

WHO Elimination Targets - Objective: Quantify the level of effort needed to eliminate HCV in Croatia based on the four WHO elimination targets. Assumptions: Reduce new infections by $80 \%$, diagnose $90 \%$ of all infections, treat $80 \%$ of eligible patients, and reduce liver-related mortality by $65 \%$, between 2015 and $2030 .^{2}$

\section{Sensitivity analysis}

Crystal Ball, an Excel add-in by Oracle, was used to run Monte Carlo simulations to generate 95\% uncertainty intervals and sensitivity analysis. Beta-PERT distributions were used for all uncertain inputs.

\section{Results}

\section{Estimates of disease burden}

At the beginning of 2018, there were an estimated 20,000 (95\% uncertainty interval (UI): 14,500 $24,000)$ viremic infections in Croatia. By the end of 

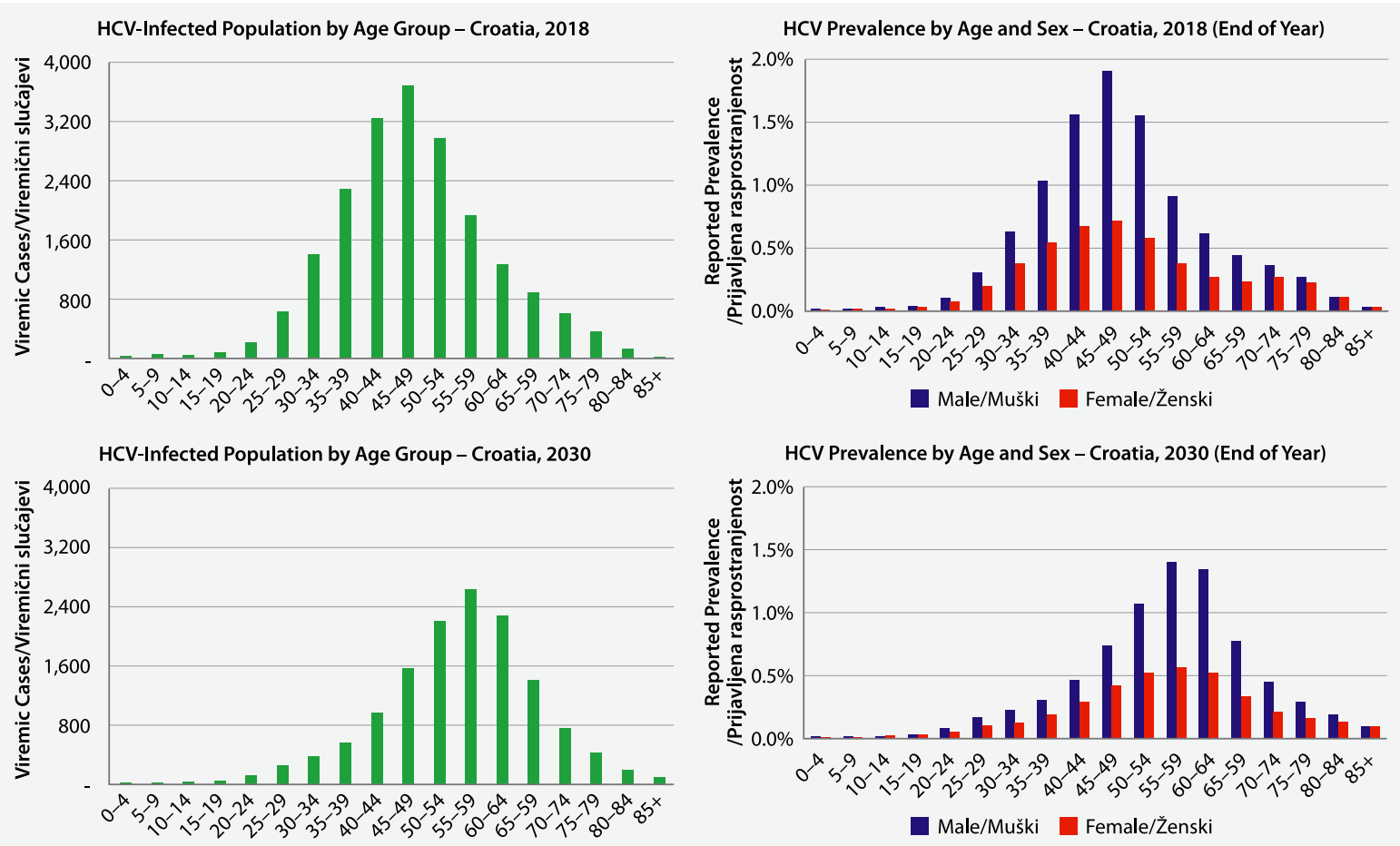

Figure 2. Age and sex distribution of hepatitis C cases, Croatia, 2018

Slika 2. Dobna i spolna distribucija slučajeva hepatitisa C u Hrvatskoj 2018. godine

2018, 19\% (n=3,700) of infections were diagnosed. Of the total infected population, only $2 \%(\mathrm{n}=470)$ were initiated on treatment. At an SVR rate of $97 \%, 460$ of these patients were estimated to be cured (Figure 1). Sixty percent of patients with HCV in 2018 were estimated to have no fibrosis or early stage fibrosis (F0$\mathrm{F} 1$ ), 30\% had F2-F3, and $10 \%$ had F4 cirrhosis or endstage liver-disease. Most infections $(\mathrm{n}=20 \%)$ were in adults aged $45-49$ years.

Under the Base, the number of viremic cases peaked in 2007 and will continue to decline by $30 \%$ between 2015 and 2030, resulting in 14,100 cases by the end of 2030. This decline is largely due to mortality. If no change is made to the HCV treatment paradigm in Croatia, liver-related deaths (LRD), incident hepatocellular carcinoma (HCC), and incident decompensated cirrhosis (DC) will increase by $70 \%, 80 \%$ and 90\%, respectively. LRD will increase from 60 in 2015 to 110 in 2030, and incident HCC will increase from 50 in 2015 to 90 in 2030. Annually, new cases of DC will also increase from 40 in 2015 to 70 in 2030 (Table 3 , Figure 3). Croatia is estimated to screen a total of 460,000 patients and diagnose 2,700 patients from 2018-2030 (Figure 4).

By screening 75,000 Croatians annually and linking $90 \%$ of newly diagnosed patients to treatment, total infections would decline by $45 \%$, but LRDs, incident HCC and incident DC would increase $45-55 \%$ from 2015-2030. Alternatively, if 100,000 Croatians are screened each year (with $90 \%$ of diagnosed patients linked to treatment), total infections would decline by $50 \%$, compared with a $20-30 \%$ increase in LRD, incident HCC and incident DC. With graduated screening and linkage to care for previously diagnosed patients, total infections would decrease $55 \%$, with a $5 \%$ reduction in LRD and $13-20 \%$ increase in HCC and DC from 2015-2030 (Table 3, Figure 3). All three enhanced screening scenarios require a 3-4-fold increase in total screenings and 2-3-fold increase in total diagnoses, compared to current practices (Figure 4).

Compared with the base scenario, eliminating $\mathrm{HCV}$ would avert 500 LRDs, 380 incident cases of HCC and 300 incident cases of DC by 2030 (Table 2). Achieving WHO elimination targets would reduce total infections by 17,000 , decrease annual LRD by 40 , and decrease incident cases of HCC and DC by 30 and 20, respectively, from 2015-2030 (Table 3, Figure 3). Elimination targets can be achieved by increasing screening, treatment, and linkage to care. Screening must ramp up to about 250,000 tests annually so that around 1,500 patients can be diagnosed and treated each year (Table 2). Compared to the Base, 5-6 times the total number of patients must be screened and diagnosed from 2018-2030 to achieve elimination targets (Figure 4).

\section{Discussion}

Now that a cure for HCV is available, case-finding has become the major obstacle to achieve elimination. 
TABLE 3. CASES OF VIREMIC HCV INFECTION, DECOMPENSATED CIRRHOSIS, HEPATOCELLULAR CARCINOMA AND LIVER-RELATED DEATHS BY SCENARIO AND PERCENT CHANGE OF CASE COUNTS BETWEEN 2018 AND 2030, CROATIA

TABLICA 3. SLUČAJEVI VIREMIČNE INFEKCIJE HCV, DEKOMPENZIRANE CIROZE, HEPATOCELULARNOG KARCINOMA I SMRTI OD BOLESTI JETRE PREMA RAZLIČITIM SCENARIJIMA I POSTOTNE PROMJENE U BROJU SLUČAJEVA OD 2018. DO 2030., HRVATSKA

\begin{tabular}{|c|c|c|c|c|}
\hline & \multicolumn{2}{|c|}{$\begin{array}{l}\text { Annual Outcomes* } \\
\text { / Godišnji Ishodi }\end{array}$} & \multicolumn{2}{|l|}{$\begin{array}{l}\text { Cumulative Outcomes } \\
\text { / Kumulativni Ishodi }\end{array}$} \\
\hline & 2015 & 2030 & $\begin{array}{l}\text { Change from } 2015 \text { to } 2030 \\
\text { / Promjene između } \\
\text { 2015. i } 2030\end{array}$ & $\begin{array}{l}\text { Incident cases averted } \\
\text { from } 2015 \text { to } 2030\end{array}$ \\
\hline \multicolumn{5}{|l|}{ Total viremic infections / Ukupni broj viremičnih slučajeva } \\
\hline $\begin{array}{l}\text { Base / Polazište } \\
\text { Screen / Testirano 75,000 } \\
\text { Screen / Testirano 100,000 } \\
\text { Graduated Screening+LTC / Probir+Uključivanje u skrb } \\
\text { WHO Elimination Targets / SZO eliminacijski ciljevi }\end{array}$ & 21,000 & $\begin{array}{c}14,100 \\
11,700 \\
10,300 \\
9,300 \\
4,000\end{array}$ & $\begin{array}{l}\downarrow 30 \% \\
\downarrow 45 \% \\
\downarrow 50 \% \\
\downarrow 55 \% \\
\downarrow 80 \%\end{array}$ & $\begin{array}{c}- \\
90 \\
150 \\
190 \\
370\end{array}$ \\
\hline \multicolumn{5}{|l|}{$\begin{array}{l}\text { Annual liver-related deaths (LRD) } \\
\text { / Godišnji broj smrti od bolesti jetre }\end{array}$} \\
\hline $\begin{array}{l}\text { Base / Polazište } \\
\text { Screen / Testirano 75,000 } \\
\text { Screen / Testirano 100,000 } \\
\text { Graduated Screening+LTC / Probir+Uključivanje u skrb } \\
\text { WHO Elimination Targets / SZO eliminacijski ciljevi }\end{array}$ & 60 & $\begin{array}{l}110 \\
90 \\
70 \\
60 \\
20\end{array}$ & $\begin{array}{l}\uparrow 70 \% \\
\uparrow 40 \% \\
\uparrow 20 \% \\
\downarrow 55 \% \\
\downarrow 65 \%\end{array}$ & $\begin{array}{l}- \\
100 \\
190 \\
290 \\
500\end{array}$ \\
\hline \multicolumn{5}{|l|}{$\begin{array}{l}\text { Incident hepatocellular carcinoma (HCC) } \\
\text { / Incidencija hepatocelularnog karcinoma (HCC) }\end{array}$} \\
\hline $\begin{array}{l}\text { Base / Polazište } \\
\text { Screen / Testirano 75,000 } \\
\text { Screen / Testirano 100,000 } \\
\text { Graduated Screening+LTC / Probir+Uključivanje u skrb } \\
\text { WHO Elimination Targets / SZO eliminacijski ciljevi }\end{array}$ & 50 & $\begin{array}{l}90 \\
80 \\
70 \\
60 \\
20\end{array}$ & $\begin{array}{l}\uparrow 80 \% \\
\uparrow 45 \% \\
\uparrow 25 \% \\
\uparrow 13 \% \\
\downarrow 60 \%\end{array}$ & $\begin{array}{c}- \\
90 \\
150 \\
200 \\
380\end{array}$ \\
\hline \multicolumn{5}{|l|}{$\begin{array}{l}\text { Incident decompensated cirrhosis (DC) } \\
\text { / Incidencija dekompenzirane ciroze }\end{array}$} \\
\hline $\begin{array}{l}\text { Base / Polazište } \\
\text { Screen / Testirano } 75,000 \\
\text { Screen / Testirano 100,000 } \\
\text { Graduated Screening+LTC / Probir+Uključivanje u skrb } \\
\text { WHO Elimination Targets / SZO eliminacijski ciljevi }\end{array}$ & 40 & $\begin{array}{l}70 \\
60 \\
50 \\
50 \\
17\end{array}$ & $\begin{array}{l}\uparrow 90 \% \\
\uparrow 55 \% \\
\uparrow 30 \% \\
\uparrow 20 \% \\
\downarrow 55 \%\end{array}$ & $\begin{array}{l}- \\
70 \\
120 \\
150 \\
300\end{array}$ \\
\hline
\end{tabular}

*End of year/Kraj godine

Based on current disease burden assumptions, the model estimates that only $20 \%$ of infected Croatians are aware of their disease status, and only $2 \%$ of the infected population began treatment in 2018. In recent years, Croatia has enhanced effort to address HCV by removing fibrosis-level treatment restrictions and increasing the number of patients initiated on treatment, however a comprehensive strategy is needed to continue the momentum of action and to guide next steps. Four intervention scenarios were modeled to inform one data-driven, national screening strategy. Results demonstrate that as screening efforts are amplified (and assuming timely linkage to treatment for most patients) morbidity and mortality will decline in tandem (Figure 3, Figure 4). Achieving WHO elimination targets by 2030 is the best-case scenario: estimated to prevent nearly 1,200 cases of end-stage disease and HCV-related mortality. To achieve WHO elimination targets, treatment will have to scale faster than screening. This means that the approach to case-finding will need to be two-pronged: 1) finding and linking previously diagnosed patients to care and 2) increasing screening to increase new diagnoses. Current screening techniques in Croatia are inefficient, with some patients tested multiple times. The high volume of unique individuals that must be screened to achieve targets means that tracking systems must be improved so patients are tested no more than once or twice. As a compliment to the national plan, a central location should be elected to house and manage these data, and data should be routinely and completely reported for tracking purposes. Currently, experts believe that the number of people diagnosed with chronic HCV may be underreported because not all data are sent to the Croatian Institute of Public Health. It is imperative that reporting systems are improved so that progress can be tracked. 

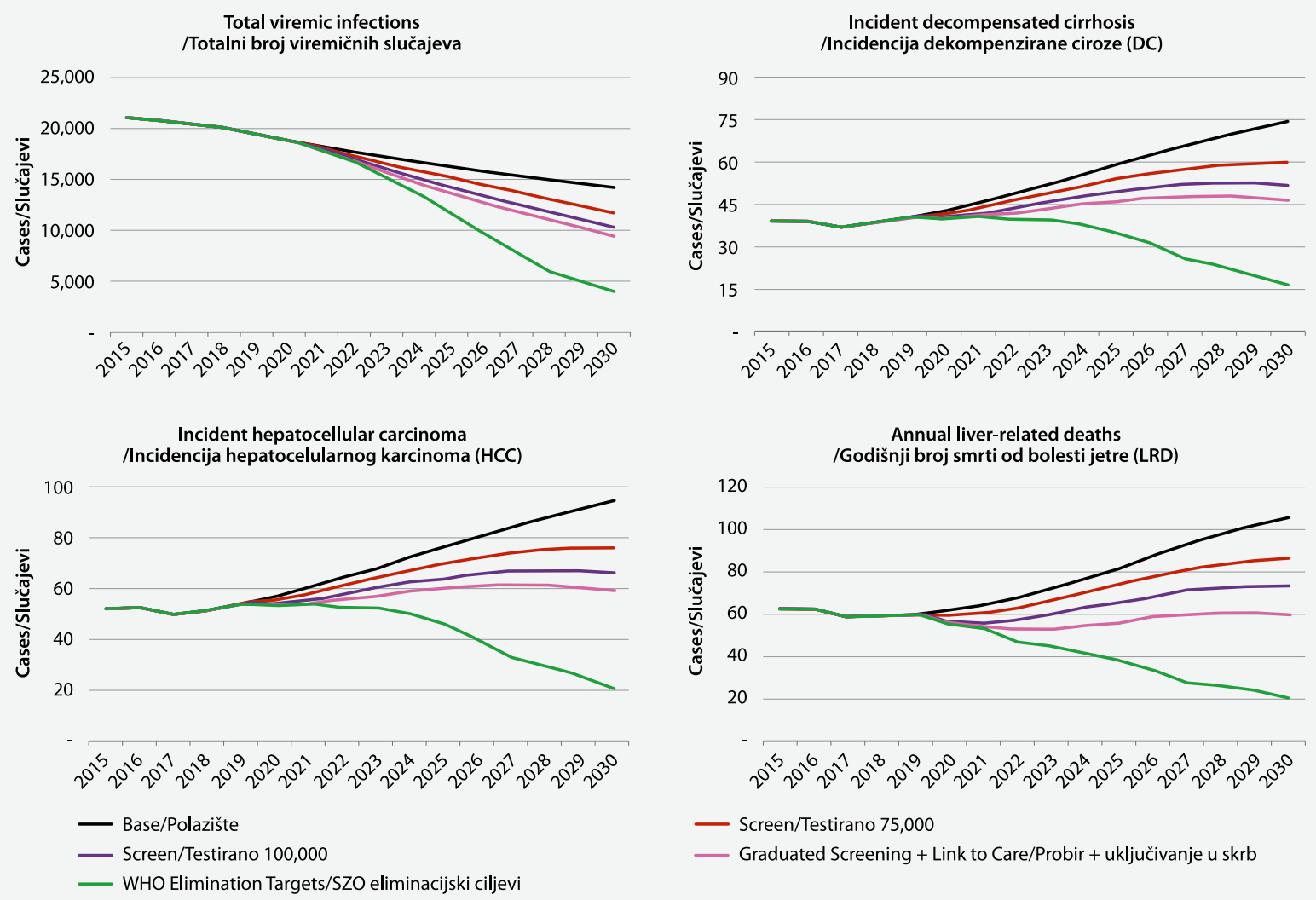

Figure 3. Total infeCted CASES, PREVAlEnt DECOMPENSATEd CirRhosis, PREVAlENT HCC, AND LIVER-RELATED DEATHS, CROATIA, 2015-2030

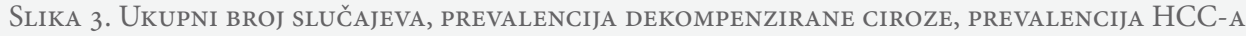

I BROJ SMRTI OD JETRENIH BOLESTI, HRVATSKA, 2015.-2030.

The next crucial decision for Croatian health authorities developing a national plan is to determine which populations to target in the screening campaign. Focused testing among high-risk groups or birth cohorts are the most common method of screening expansion, both shown to be cost-effective. ${ }^{19}$ Most new infections occur among PWID, however, social stigma is a significant barrier to case identification. Blood donation centers in Croatia refer a significant number of patients to primary care testing, reporting that many at-risk individuals seek testing at blood banks to avoid disclosing risky behaviors. Screening can be effectively conducted in these at-risk populations to reduce transmission; however, innovative campaigns are needed to identify patients who may not self-identify with a risk factor. According to our analysis, of all chronic HCV infections, $14 \%$ were estimated to be active PWID, with the remainder of infections occurring among persons with other or unknown risk factor (including but not limited to former-PWID, nosocomial or transfusion related risks, etc.). In the absence of comprehensive estimates of populations based on risk, the age distribution of the infected population
(Figure 2) could be used to inform or support agebased (or birth cohort) screening conducted in primary care settings. As part of the awareness campaign, experts envision expanding annual screening counts from about 40,000 Croatians (current) to 75,000 Croatians, starting in 2020, with a focus on primary care settings (Appendix, Section 4). Primary care facilities currently outsource all laboratory testing; however, experts agree that screening capacity can be significantly ramped-up if conducted in-house. This would involve a comprehensive, national action plan focused on increased testing capacity in primary care settings and maintaining screening levels in other settings. Significant investment would be needed to reach these goals; however, aggressive implementation of prevention and treatment strategies has been shown to reduce longterm economic and societal costs associated with $\mathrm{HCV}^{20-22}$ In other country settings, agencies such as the World Bank have also loaned monetary support for the up-front cost of HCV screening. ${ }^{23}$

Slight but significant changes were made to this analysis compared to previous reports. Guided by expert review and approval, this report updates data in 

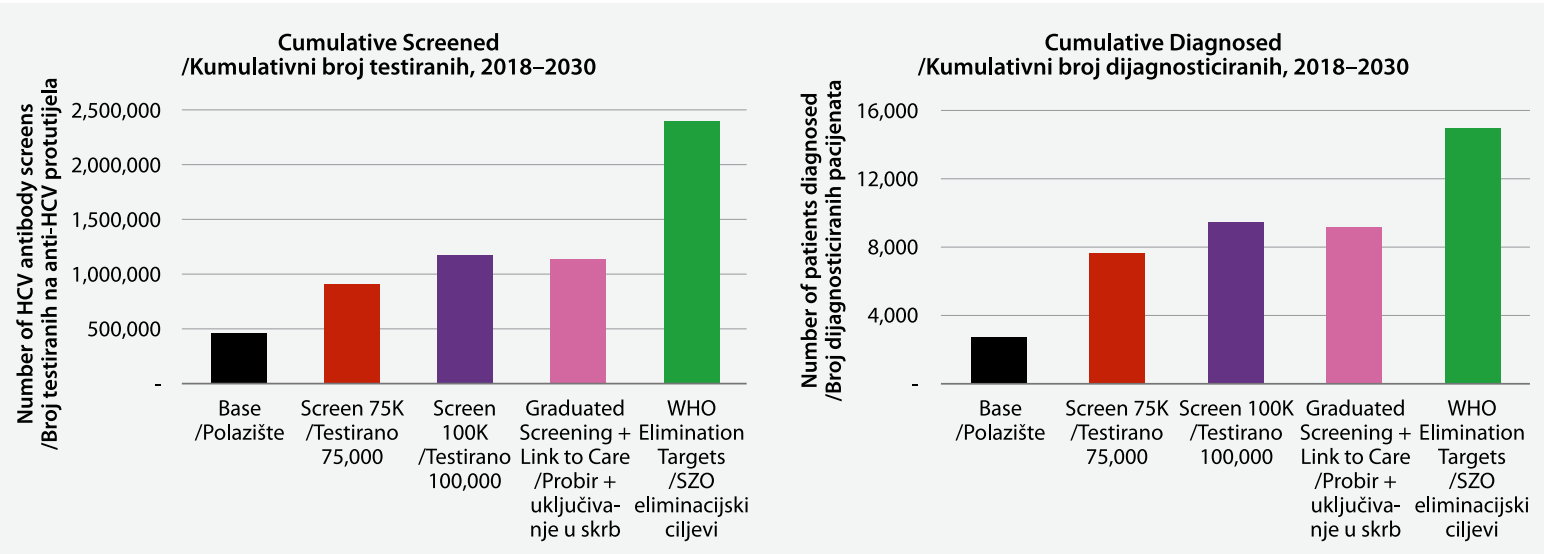

Figure 4. Cumulative NUMber OF PATIENTS SCREENED AND DIAGNOSED, BY SCENARIO, CROATIA, 2018-2030

Slika 4. Kumulativni broj testiranih i Dijagnosticiranih Pacijenata PREMA SCENARIJU 2018.-2030.

the 2016 analysis ${ }^{4}$ for the following epidemiological characteristics: genotype, fibrosis and age treatment restrictions, population diagnosed, population treated, and number of HCV-related liver transplants. Compared to the 2016 analysis, estimates for the population diagnosed increased and estimates for the population treated decreased, resulting in fewer total cases and fewer end-stage outcomes but similar disease burden trends overall. ${ }^{5}$ Epidemiological data were also validated, when available. Data from local diagnosis registries (the distribution of prevalent cases by age and sex for 2018) were used to compare the distribution of cases by age and sex in the model for 2018. As well, one prominent healthcare facility in Croatia reported that about $60 \%$ of diagnosed cases were male, validating the sex distribution used in the model (about 55\% male). ${ }^{24}$ A sensitivity analysis was conducted to account for the depleting pool of infected individuals over time, expected to occur with the success of the screening campaign (Appendix, Section 3).

Limitations inherent to modelling affected this analysis, including the estimation of disease burden based on multiple data sources. Application of the Delphi process, however, ensured that the data were reviewed and vetted by experts and determined to be the best available. Shortcomings in data quality, however, make it difficult to model screening scenarios because current diagnosis and screening data are likely under-reported. Once a formal screening campaign included in a national action plan begins, the data should be used to re-evaluate progress toward elimination and strategic plans. It is also important to acknowledge that projections are dependent on the data inputs and assumptions. The model assumes that DAAs are consistently available to the diagnosed population and that treatment uptake, initiation and retention will remain high, even in difficult-to-treat populations. However, realworld fluctuations in these variables over time could impact projections.

\section{Findings}

If WHO elimination targets are achieved, 500 liverrelated deaths and 680 cases of hepatocellular carcinoma and decompensated cirrhosis could be prevented, and viremic cases of $\mathrm{HCV}$ could be reduced from 21,000 to 4,000 between 2015 and 2030. Elimination requires a coordinated effort between various country and industry leaders including government authorities, policymakers and healthcare and insurance providers. Improved screening mechanisms and patient registries (for tracking screening and diagnosis) will be needed for the scale-up required to achieve goals.

\section{Declarations}

\section{Statement on Financial and Other Relationships}

This project was supported by Gilead Sciences. Gilead Sciences had no input on the content, study design, data selection, decision to publish, or preparation of the manuscript.

\section{Acknowledgments}

The authors gratefully thank the following organizations for their involvement in consultations in forming this analysis: the Croatian Institute of Public Health, University Hospital of Infectious Disease Zagreb, Split University Hospital, Merkur Hospital Zagreb, Croatian Health Insurance Fund and Hepatos. 


\section{APPENDIX}

\section{SECTION 1.}

\section{Data available for epidemiological inputs}

Reports of the number of patients diagnosed with chronic HCV were provided by in-country experts for 2014-2018. Case counts were adjusted assuming 80\% were viremic (expert input). Experts agree underreporting exists in Croatia, as some patients seek anonymous testing in blood donor clinics and these cases are not consistently reported. The rate of underreporting is unknown; however, experts estimate about $20 \%$ of the total infected population is diagnosed. The data shown in Table 1 represent known diagnosed cases, however true estimates are likely higher. Annual treatment estimates were based on the number of patients covered by insurance and therefore received DAAs, and an additional cohort who obtained treatment from alternative sources (expert input).

\section{SECTION 2.}

Description of the screening module in the $\mathrm{HCV}$ disease burden model

The screening module was developed to calculate the number of screening tests necessary to diagnose a given number of HCV-infections. The module used aforementioned epidemiological inputs (the infected population stratified by age and the number of annual diagnoses) to calculate the population eligible for screening, i.e., the undiagnosed, HCV-infected population that was either asymptomatic or not linked-tocare.

In the model, the more advanced stages of liver disease were assumed to be diagnosed first. It was also assumed that cases of spontaneous clearance were diagnosed at the same rate as asymptomatic, chronically infected cases.

To calculate the size of the population eligible for screening, the module tracked the populations with a history of screening, diagnosis, or SVR. It was assumed that each individual would receive at most one HCV antibody screen, and populations with a history of diagnosis or SVR would be excluded from future screening. Populations outside of the age range eligible for screening were excluded.

The number of patients needed to screen (NNS) to find one HCV antibody positive case was calculated, as shown in Equations 1-2. We then calculated the annual number of HCV antibody screens performed (Equation 3), of which all HCV antibody-positive tests were assumed to receive confirmatory HCV RNA testing. The case-finding algorithm assumed that persons with advanced liver disease were symptomatic and would seek care with or without active screening campaigns. Thus, each newly diagnosed case of advanced liver disease was assumed to require two screens; one HCV antibody and one confirmatory HCV RNA test.

Equation 1. Number needed to screen to diagnose one HCV antibody-positive case, unadjusted, in year $t$

$$
\mathrm{NNS}_{t}^{*}=\frac{1}{\frac{\text { Undiagnosed, asymptomatic or not linked-to-care HCV antibody-positive cases }_{t}}{\text { Population eligible for screening } t_{t}}} \text {, where }
$$

Population eligible for screening s $_{t}$ was the population eligible for screening in year $t$. Eligibility of screening was determined by birth year (by scenario), history of having received a screen within the screening strategy (excluded), history of diagnosis (excluded), and history of SVR (excluded).

Equation 2. Number needed to screen to diagnose one HCV antibody-positive case, adjusted, in year $t$ $\mathrm{NNS}_{t}=\frac{\mathrm{NNS}_{t}^{*}}{k}$, where

$\mathrm{NNS}_{t}^{*}$ is the number needed to screen to diagnose one HCV antibody-positive case, unadjusted, in year $t$;

$k$ is the ratio of prevalence in the population where the screening is conducted to that in the general population.
Equation 3. Number of HCV antibody screens performed, in year $t$

Newly diagnosed symptomatic HCV antibodypositive cases ${ }_{t}+\mathrm{NNS}_{t} \times$

Newly diagnosed asymptomatic or not yet linkedto-care cases, where

NNS is the number needed to screen to diagnose one HCV antibody-positive case in year $t$. 
Appendix Table 1. Sensitivity analysis Calculating the aVerage number of Patients diagnosed

Dodatak tablica 1. Analiza osjetljivosti u izračunu ProsjeČnog broja Dijagnosticiranih

\begin{tabular}{|c|c|c|c|c|c|c|c|c|c|c|c|c|c|c|c|c|c|c|c|c|c|c|c|}
\hline & \multicolumn{22}{|c|}{ Average Annual Diagnosed (ages 15+) / Prosječni broj dijagnosticiranih godišnje (dob 15+), 2020-2030 } \\
\hline & & 150 & 200 & 250 & 300 & 350 & 400 & 450 & 500 & 550 & 600 & 650 & 700 & 750 & 800 & 850 & 900 & 950 & 1,000 & 1,050 & 1,100 & 1,150 & 1,200 \\
\hline \multirow{10}{*}{ 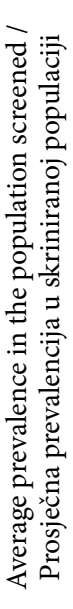 } & $0.46 \%$ & & & & & & & & & & & & & & & & & & & & & & \\
\hline & $0.57 \%$ & & & & & & & & & & & & & & & & & & & & & & \\
\hline & $0.69 \%$ & & & & & & & & & & & & & & & & & & & & & & \\
\hline & $0.80 \%$ & & & & & & & & & & & & & & & & & & & & & & \\
\hline & $0.91 \%$ & & & & & & & & & & & & & & & & & & & & & & \\
\hline & $1.03 \%$ & & & & & & & & & & & & & & & & & & & & & & \\
\hline & $1.14 \%$ & & & & & & & & & & & & & & & & & & & & & & \\
\hline & $1.26 \%$ & & & & & & & & & & & & & & & & & & & & & & \\
\hline & $1.37 \%$ & & & & & & & & & & & & & & & & & & & & & & \\
\hline & $1.48 \%$ & & & & & & & & & & & & & & & & & & & & & & \\
\hline
\end{tabular}

Screening an average of 40,000 people per year / Prosječni probir od 40,000 osoba godišnje

Screening an average of 75,000 people per year / Prosječni probir od 75,000 osoba godišnje

Screening an average of 100,000 people per year / Prosječni probir od 100,000 osoba godišnje

\section{SECTION 3.}

\section{Screening model sensitivity analysis}

Appendix Table 1 shows the number of patients we would expect to be diagnosed annually, based on the average number of patients screened each year for 2020 through 2030. An average was calculated to account for the depleting pool of infected individuals over time that necessitates additional screens. A range of 1 to 3 times the 2018 viremic prevalence $(0.46 \%-$ $1.48 \%$ ) was used to account for screening practices in the general and at-risk populations. A sensitivity of +/- 20\% was also considered. Results were as follows:

- Screening an average of 40,000 people/year results in an average of 200-650 new viremic diagnoses annually.

- Screening an average of 75,000 people/year results in an average of 350-900 new viremic diagnoses a year.

- Screening an average of 100,000 people/year results in an average of 450-1,1500 new viremic diagnoses a year.

\section{SECTION 4.}

\section{Targeted population screening}

Experts estimate that at least 40,000 Croatians were screened in 2018. The majority were tested in blood banks, with no tests conducted in primary care setting (expert input; Dr. Vince). Experts envisioned a goal of
ApPendix TABle 2. TARgETED POPUlation SCREENING CURRENTLY IN PLACE (2018) AND PROJECTED IN 2020 TO REACH 75,000 SCREENS, CROATIA

TABLICA 2. AKTUALNI CILJANI PROBIR U 2018. I PROJEKCIJA ZA 2020. S DOSEGOM 75.000 TESTIRANIH

\begin{tabular}{|c|c|c|c|}
\hline $\begin{array}{l}\text { Population } \\
\text { / Populacija }\end{array}$ & $\begin{array}{l}\text { Risk of infec- } \\
\text { tion in the } \\
\text { population* } \\
\text { / Rizik } \\
\text { infekcije u } \\
\text { populaciji }\end{array}$ & $\begin{array}{l}\text { Number } \\
\text { screened } \\
\text { in } 2018 \\
\text { / Broj } \\
\text { testiranih } \\
\text { u } 2018 \text {. }\end{array}$ & $\begin{array}{l}\text { Number to } \\
\text { screen } \\
\text { starting in } \\
2020 \text { / Broj } \\
\text { testiranih } \\
\text { od } 2020 .\end{array}$ \\
\hline $\begin{array}{l}\text { Blood banks } \\
\text { / Transfuziologija }\end{array}$ & $\begin{array}{l}\text { Low } \\
\text { / nizak }\end{array}$ & 30,000 & 30,000 \\
\hline $\begin{array}{l}\text { Voluntary centers } \\
\text { / Centri za } \\
\text { dobrovoljno } \\
\text { testiranje }\end{array}$ & $\begin{array}{l}\text { High } \\
\text { / visok }\end{array}$ & 5,000 & 5,000 \\
\hline $\begin{array}{l}\text { Primary care/ } \\
\text { Laboratories } \\
\text { / Primarna } \\
\text { zdravstvena zaštita/ } \\
\text { različiti laboratoriji }\end{array}$ & $\begin{array}{l}\text { Mixed } \\
\text { / mješovit }\end{array}$ & 4,500 & 39,500 \\
\hline \multirow[t]{2}{*}{$\begin{array}{l}\text { Screening vans } \\
\text { / Testiranje u } \\
\text { zajednici/mobilne } \\
\text { jedinice }\end{array}$} & $\begin{array}{l}\text { High } \\
\text { / visok }\end{array}$ & 500 & 500 \\
\hline & Total / Ukupno & 40,000 & 75,000 \\
\hline
\end{tabular}

* Risk of infection in the population is defined as follows: Low - same prevalence $(1 \mathrm{x}$ ) as the general Croatian population; High - 3x general population prevalence (on average); Mixed - $2 x$ general population prevalence (on average) / Rizik infekcije u populaciji je definiran na slijedeći način: nizak - ista prevalencija kao u općoj populaciji; visok - 3x veća prevalencija nego u općoj populaciji; mješovit - $2 x$ veća prevalencija nego u općoj populaciji

Primary care facilities do not screen in-house, but outsource to laboratories (i.e. the 4,500 screened in 2018) / Testiranje se ne obavlja u ambulantama obiteljske medicine, nego se pacijenti upućuju u različite laboratorije koji pružaju tu uslugu 
75,000 Croatians screened annually, starting in 2020 (Appendix Table 2). This would involve initiating a national action plan including an awareness campaign in primary care settings and maintaining testing levels in other settings.

\section{REF E R E N C E S}

1. World Health Organization. Data and statistics. 2019. http:// www.euro.who.int/en/health-topics/communicable-diseases/hepatitis/data-and-statistics (accessed October 22 2019).

2. Blach S, Zeuzem S, Manns $M$, et al. Global prevalence and genotype distribution of hepatitis $C$ virus infection in 2015: a modelling study. Lancet Gastroenterol Hepatol 2016;2(3): 161-76.

3. Kanwal F, Kramer J, Asch SM, Chayanupatkul M, Cao Y, ElSerag HB. Risk of Hepatocellular Cancer in HCV Patients Treated With Direct-Acting Antiviral Agents. Gastroenterology 2017;153(4):996-1005.e1.

4. Maaroufi A, Vince A, Himatt SM, et al. Historical epidemiology of hepatitis $C$ virus in select countries-volume 4. J Vir Hep 2017;24:8-24.

5. Chen DS, Hamoudi W, Mustapha B, et al. Strategies to manage hepatitis $C$ virus infection disease burden-Volume 4. J Vir Hep 2017;24:44-63.

6. Chan HLY, Chen CJ, Omede O, et al. The present and future disease burden of hepatitis $C$ virus infections with today's treatment paradigm: Volume 4. J Vir Hep 2017;24:25-43.

7. Örmeci N, Malhan S, Balık I, Ergör G, Razavi H, Robbins S. Scenarios to manage the hepatitis $C$ disease burden and associated economic impact of treatment in Turkey. Hepatology International 2017;11(6):509-16.

8. Razavi H, Robbins S, Zeuzem S, et al. Hepatitis C virus prevalence and level of intervention required to achieve the WHO targets for elimination in the European Union by 2030: a modelling study. Lancet Gastroenterol Hepatol; 2(5):325-36.

9. Croatian Institute for Public Health. Croatian National Cancer Registry. Cancer Incidence in Croatia in 2016.Bulletin No 41. Zagreb, Croatia, 2019.

10. Croatian Institute for Public Health. Izviješće o umrlim osobama u Hrvatskoj u 2018. godini (Mortality Report), 2019.
11. Vilibic-Cavlek T, Kucinar J, Ljubin-Sternak S, Kaic B, LazaricStefanovic L, Kolaric B. Prevalence of viral hepatitis in Croatian adult population undergoing routine check-up, 20102011. Cent Eur J Public Health 2014;22(1):29-33.

12. Blach S. Personal communication with Croatian experts Dr. Irena Hrstic, Dr. Boris Lukšić, Dr. Miro Morović, Diana Nonković, Tatjana Reic and Dr. Adriana Vince. 2015.

13. Vince A, Zidovec Lepej S, Bingulac-Popovic J, et al. Distribution of hepatitis $C$ virus genotypes and subtypes in Croatia: 2008-2015. Cent Eur J Public Health 2018;26(3):159-63.

14. Croatian Institute for Public Health. Communicable diseases in Croatia in 2016, 2017.

15. Kolaric B, Stajduhar D, Gajnik D, Rukavina T, Wiessing L. Seroprevalence of blood-borne infections and population sizes estimates in a population of injecting drug users in Croatia. Cent Eur J Public Health 2010;18(2):104-9.

16. Croatian Institute for Public Health. Report on persons treated for drug abuse in Croatia in 2017, 2018.

17. IRODaT. International Registry on Organ Donation and Transplantation. 2016. http://www.irodat.org/?p=database\&c =MY\#data2016). Accessed: December 23, 2019.

18. Croatian Institute for Public Health. Recommendation for the treatment of hepatitis C, Hrvatska 2019. 2019. www.bfm.hr.

19. Morgan JR, Servidone M, Easterbrook P, Linas BP. Economic evaluation of HCV testing approaches in low and middle income countries. BMC Infect Dis 2017;17(Suppl 1):697.

20. Benzaken AS, Girade R, Catapan E, et al. Hepatitis C disease burden and strategies for elimination by 2030 in Brazil. A mathematical modeling approach. Braz J Infect Dis 2019.

21. Gountas I, Sypsa V, Papatheodoridis G, et al. Economic evaluation of the hepatitis $C$ elimination strategy in Greece in the era of affordable direct-acting antivirals. World J Gastroenterol 2019;25(11):1327-40.

22. Blach S, Schaetti C, Bruggmann P, Negro F, Razavi H. Costeffectiveness analysis of strategies to manage the disease burden of hepatitis C virus in Switzerland. Swiss Med Wkly 2019; 149:w20026.

23. Omran H. World Bank to lend Health ministry $\$ 200 \mathrm{~m}$ for hepatitis C screening: minister. Daily News Egypt 2018 March 28, 2018.

24. Medical School University of Zagreb University Hospital of Infectious Diseases. Zagreb, Croatia; 2019.

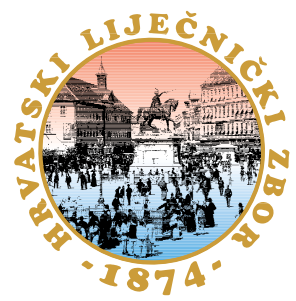

